\section{Chemical Control of Plains Pricklypear in Southeastern Wyoming}
A. P. THATCHER, G. V. DAVIS, AND H. P. ALLEY
Range Conservationists, U. S. Soil.Conservation Service, Casper and Torrington, Wyoming, and Assistant Pro- fessor, Department of Plant Science, University of Wyo- ming, Laramie

The invasion and increase of plains pricklypear (Opuntia polyacantha) has become an acute problem in many range areas of Wyoming. The Soil Conservation Service recently estimated that $1,500,000$ acres were infested to such an extent that control measures are necessary to permit restoration of the excellent range condition class within a reasonable period. In many places it has increased from less than 2.5 percent of the total annual production, by weight, to over 60 percent.

Wyoming ranchers have long used such practices as burning, railing and blading in attempts to control the pricklypear. These methods ordinarily gave unsatisfactory control or were uneconomical. A review of range herbicide literature, (Thomas, 1956) (Hoffman et al., 1955) (Young, 1951) (Cornelius, 1951), and correspondence with researchers in this field, indicated that several herbicides might prove both effective and economically feasible.

Most herbicides are not readily absorbed by the plains prickly- pear. The pads are covered with a thick cutin layer and the stomata, through which the herbicide might enter the vascular system, are open only at night (Daubenmire, 1956). Moreover, the herbicide must enter largely through stems (pads) since the true leaves are extremely small and present for only a short time during favorable moisture conditions in the spring. Therefore, to increase the absorption by the plant, the puncturing or other mechanical damaging of the pads, just prior to the application of herbicides, was considered as a means of getting more of the chemical into the vascular system.

\section{Experimental Area}

All of these field trials were established on the Morton ranch, 15 miles northwest of Douglas, Wyoming. This area receives an average of approximately 11 inches of precipitation annually. Elevation is about 5,000 feet above sea level. The trials were located on normal sandy loam soils (Sandy range site) where response of the vegetation in the
Poor range condition class could be checked against response in the Good condition class. Plots were not grazed during the 1961 , 62 and 63 growing seasons.

Associated species on the plots included needle and thread (Stipa comata), western wheatgrass (Agropyron smithii), sand dropseed, (Sporobolus cryptandrus), blue grama (Bouteloua gracilis), prairie junegrass (Koeleria cristata), bottlebrush squirreltail (Sitanion hystrix), Sandberg bluegrass (Poa secun$d a$ ), cheatgrass brome (Bromus tectorum), sixweeks fescue (Festuca octoflora), big sagebrush (Artemisia tridentata), prairie pepperweed (Lepidium densiflorum), tansey mustard (Sophia pinnata), annual sunflower ( $\mathrm{He}$ lianthus annuus), curlycup gumweed (Grindelia squarrosa), pale evening primrose (Oenothera albicaulis) and threadleaf sedge (Carex filifolia).

\section{Methods and Procedures}

On June 1, 1961, 1x2 rod plots of pricklypear infested rangeland were treated with 2,4,5Trichlorophenoxy acetic acid (2,4,5-T), 2,3,6 Trichlorobenzoic acid (2,3,6 TBA) and 2,4,5 Trichloropropionic acid (silvex) at various rates and combinations shown in Table 1. Each treatment was replicated three times. The object of this initial project was to select those herbicides and combinations most effective 
for later use in larger scale trials.

Half of each plot was mechanically treated to injure the cactus plants prior to the chemical application. A cultipacker was pulled over the plants in such a manner that most of them were punctured, broken, or otherwise injured. Chemicals were applied with a hand-type boom sprayer immediately after mechanical treatment before the wounds could dry. The 2,4,5-T

Table 1. Control of plains pricklypear in 1961 trials using 2,4,5-T; 2,3,6 TBA and silvex with various carriers with and without prior mechanical treatment.

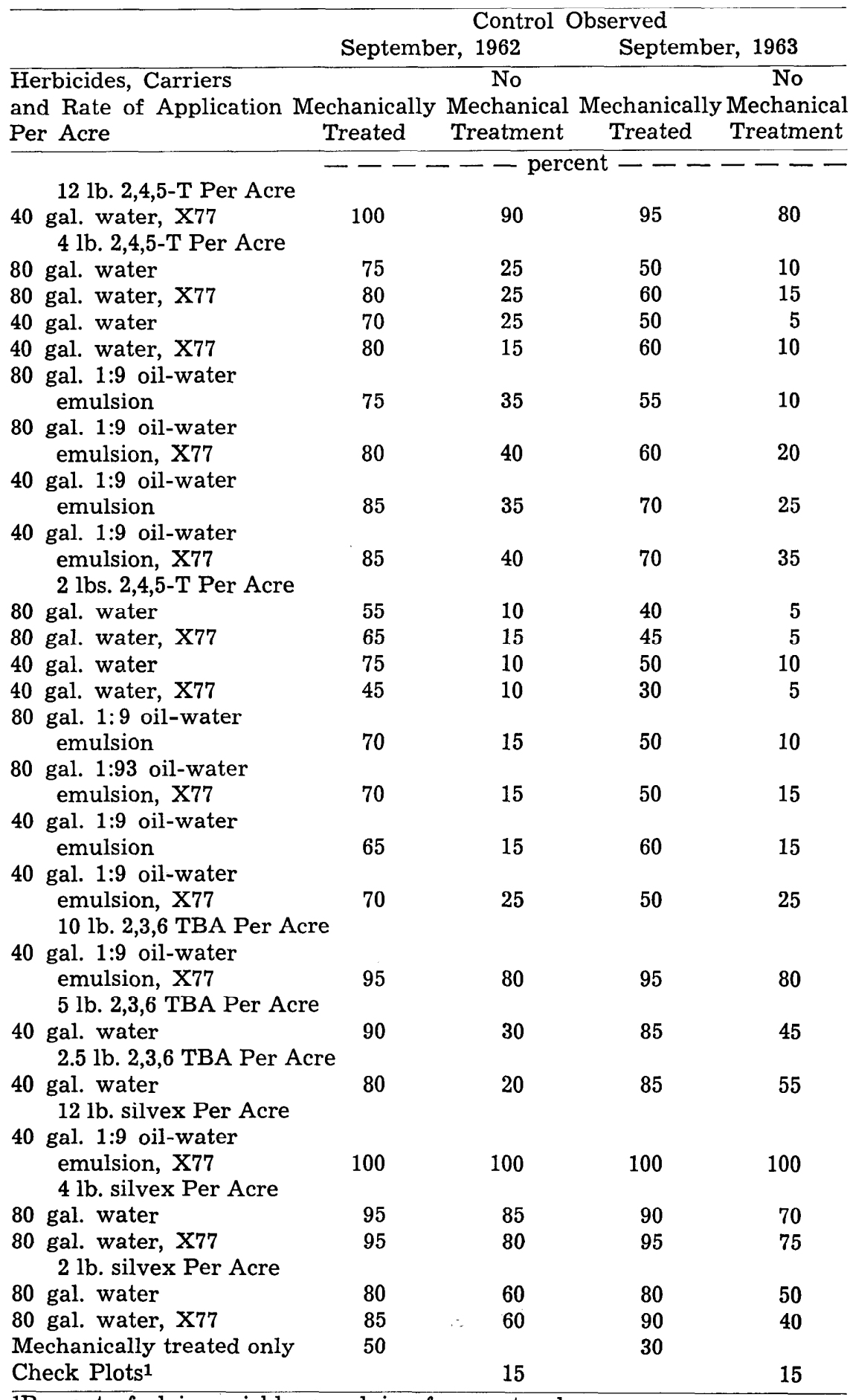

was applied at 2 and 4 pounds per acre (active) using all of the various combinations possible with 40 and 80 gallons of water and with 40 and 80 gallons of a 1:9 diesel oil-water emulsion. In addition, each of the above combinations was also applied with the X77 spreading agent. 2,4,5-T was also applied at a rate of 12 pounds per acre using 40 gallons of 1:9 diesel oil-water emulsion with the spreading agent.

2,3,6 TBA was applied at a rate of 2.5 and 5 pounds in 40 gallons of water per acre. A high rate of 10 pounds of $2,3,6$ TBA per acre using 40 gallons of 1:9 diesel oilwater emulsion with the X77 spreading agent was also applied.

Silvex was applied at a rate of 2 and 4 pounds per acre using 80 gallons of water, with and without the X77 spreader. It was also applied at 12 pounds per acre using 40 gallons of 1:9 diesel oil-water emulsion per acre with the spreading agent.

The soil moisture was 8 to 10 inches deep at the time of application. Nearly all of the associated vegetation was green and growing. The true leaves were present on the pricklypear plants. The area, which had just experienced a severe prolonged drouth, received average precipitation during the 1961 growing season. Moisture conditions continued to be average or slightly above during the 1962 and 1963 seasons. Thus response of the associated vegetation could be studied in connection with the effects of herbicides on the pricklypear.

The second trial was initiated on June 27, 1962. Silvex (Kuron), which had proven to be most effective in controlling the pricklypear in the 1961 trials, was applied on larger plots to learn if the results could be duplicated. As shown in Table 2, it was applied at two and four pounds per acre using 40 gallons of water with the X77 spreading agent, on acre plots containing a 
Table 2. Control of plains pricklypear, 1962 trials with silvex in 40 gallons water and X77 spreader with and without prior mechanical treatments, on one-acre plots. Evaluated September, 1963.

Percent

Rates of silvex

Control

$2 \mathrm{lbs}$.

no mechanical treatment

65

2 lbs.

with mechanical treatment

90

4 lbs.

no mechanical treatment

85

$4 \mathrm{lbs}$.

with mechanical treatment

Mechanical treatment only

99

25

considerable amount of pricklypear. These same rates also were applied on acre plots which had been mechanically treated. Another acre plot was mechanically treated only.

A cultipacker was used to mechanically treat the plots, as in the first experiment. Approximately 40 percent of the cactus pads were injured by either puncturing or breaking. The herbicide was applied within an hour after the mechanical treatment with a truck-mounted boom-type sprayer operating at 40 pounds p.s.i. Wind velocities less than $5 \mathrm{mph}$, moderate humidity and a temperature of about $80^{\circ} \mathrm{F}$ made conditions ideal for spraying. All of the vegetation was green and growing. There was ample moisture available for plant growth. The pricklypear was in the bloom stage and still held most true leaves.

Percent control as recorded from these trials were the average of three individuals making separate ocular estimates. The individual estimates did not vary more than 10 percent and in most cases were less than 5 percent.

\section{Results and Discussion}

Ocular estimates were made of the percent of plains pricklypear on the initial (1961) trials. The plots kill were read in September of 1962 and again in Sep- tember of 1963. Thus the plot records show results through three complete growing seasons. Table 1 shows the observed control each year in this trial.

Table 2 shows the amount of control obtained on the acre plots established in 1962. The ocular estimates were made in September of 1963, after two growing seasons.

2,4,5-T.-The best pricklypear control was obtained using the 12 pounds per acre application; however, all of the associated vegetation was severely damaged. The 2 and 4 pound rates killed most of the forbs and brush species, but did not noticeably effect the associated grass species. 2,4,5-T applied at the 4 pound per acre rate gave the next best pricklypear control. The least control was obtained using the 2 pound rate.

All of the rates were most effective when used in combination with the mechanical treatment. 2,4,5-T without any mechanical injury resulted in a maximum of 40 percent control. Mechanical injury to the pricklypear plants approximately doubled the percent of control. Using a carrier of 1:9 diesel oilwater emulsion increased the percent control approximately 10 percent over the use of water alone. The spreading agent X77 also seemed to increase the effectiveness of the chemical. The amount of carrier applied per acre made little difference in the control obtained.

\section{2,3,6 TBA.-A maximum of 95} percent control was obtained using a 10 pound per acre application on mechanically treated plots. The 2.5 and 5 pound rates also gave good initial control, but all of the associated vegetation was severely damaged, regardless of the type of treatment. The most severe damage occurred using the 10 pound rate. The plots were still nearly devoid of any vegetation, with the exception of some plains prickly- pear, after three growing seasons.

Silvex.-Silvex applied on the initial trials at a rate of 12 pounds per acre, in a carrier of 1:9 oil-water emulsion with the X77 spreading agent added, resulted in complete control of the pricklypear. However, all of the associated vegetation, with the exception of Carex filifolia, was severely damaged. The 2 and 4 pound rates, applied with a water carrier, resulted in no damage to the associated grass species. Forbs and brush species were, however, completely killed.

Mechanically treating the plots increased the control percentage. Four pounds of silvex applied on the mechanically treated plot resulted in 90 to 95 percent control. The 2 pound rate resulted in 80 to 90 percent control. The application of chemicals without mechanical treatment reduced the effectiveness as much as 30 percent. The addition of the X77 spreading agent seemed to increase, somewhat, the effectiveness of the herbicide.

Two and 4 pound rates of silvex were superior to the other chemicals in the trial as they resulted a desirable pricklypear control and still did not damage the range grasses. These rates applied to the one-acre plots (1962 trials) again resulted in very good control. As shown in Table 2 , the 4 pound rate applied with mechanical treatment resulted in nearly complete control (99 percent) of plains pricklypear. The 2 pound rate on the mechanically treated plot reduced the control received to 90 percent. Herbicides applied in the absence of mechanical treatment were less effective from 15 to 25 percent. The expanded 1962 trials largely confirmed results from the earlier smaller trials. Silvex did not damage any of the grass species in the associated vegetation; however, nearly 90 percent of the big sagebrush was killed, along with 
most of the annual and perennial forbs.

\section{Prior Mechanical Treatment.-} Mechanically treating plains pricklypear, prior to applying herbicides, greatly increased the kill of pricklypear, except where high rates of chemicals were used. It was not determined whether the increased control resulted from an extra amount of herbicide entering the vascular system through the injured tissues, or from the physical damage to the plant, or a combination of both.

An appraisal of the initial trials, near the close of the second growing season, indicated approximately 50 percent of the plans pricklypear control could be attributed to mechanical injury. However, at the end of the third growing season (September 1963), the amount of pricklypear had increased to where only 30 percent of the cactus had been controlled. The 1962 trials showed that approximately 25 percent of the pricklypear was controlled by mechanical injury alone by the end of the second growing season.

Some of the pricklypear apparently died from natural causes during 1962 and 1963. Approximately 15 percent of the plains pricklypear was destroyed in the check plots. The area received an above normal amount of moisture during the 1962 and 1963 spring and early summer months. A number of insects, notably the pricklypear bug (Chelinidea vittiger) and Northern cochineal mealy bug (Dactyloplus sp.) invaded the numerous cactus patches. A number of pricklypear pads were observed to have been hollowed out by some insect.
There was evidence that the plains pricklypear would reinvade the rangeland if conditions were favorable. After three growing seasons, the 1961 trials showed an increase of 10 to 25 percent in the amount of pricklypear. The largest increases were on those plots with poor kills. As stated previously, these plots were established on poor condition rangeland where competition between the plains pricklypear and native perennial grasses would not be as great as on better condition ranges. No general increase was noticed on the 1962 acre size plots which were established on rangeland in good condition.

\section{Summary}

Field trials to chemically control plains pricklypair were conducted near Douglas, Wyoming during the spring seasons of 1961 and 1962. Results were recorded through three growing seasons. 2,4,5-T, 2,3,6 TBA and silvex were applied as sprays to plains pricklypear in various rates and with various kinds and amounts of carriers during the spring of 1961. Half of each plot was mechanically treated with a cultipacker so as to puncture or injure the pricklypear plant just prior to applying the herbicides. Silvex was generally superior to the others herbicides. In 1962, 2 and 4 pounds of silvex were applied to mechanically treated and non-mechanically treated acre-size plots. The results of these two trials can be summarized as follows:

1. Silvex proved to be superior to 2,3,6 TBA and 2,4,5-T when applied at 2 and 4 pounds per acre. These rates proved effective in controlling plains pricklypear and did not injure any of the desirable range grasses. These rates also effectively controlled the big sagebrush.

2. Prior mechanical injury of pricklypear plants greatly increased the effectiveness of all the herbicides except those applied at the 10 and 12 pound rates.

3. Mechanical injury alone contributed approximately 25 to 30 percent of the control.

4. 2,3,6 TBA damaged or killed most of the desirable range plants at all rates. The high rates of silvex and 2,4,5-T also damaged some of the desirable forage plants.

5. Approximately 15 percent of the plains picklypear control resulted from insect damage and other natural causes.

6 . The estimated cost of applying 2 and 4 pound rates of silvex would be $\$ 8$ to $\$ 14$ per acre respectively which includes cost of mechanical injury and application of chemical.

\section{LITERATURE CITED}

CoRnelius, D. R. ET AL. 1959. Handbook, Chemical Control of Range Weeds. U. S. Department of Agriculture, U. S. Department of the Interior, Range Seeding Equipment Committee. (Revised) $44 \mathrm{pp}$.

DAUBenmire, R. F, 1958. Plants and Environment, A Textbook of Plant Autecology. John Wiley \& Sons, Inc., New York, N. Y. 424 pp.

HofFMan, G. O., WALKER, A. H., AND DARRow, R. A. 1955. Pricklypear Good or Bad. Texas Agricultural Extension Service Bulletin 806.

Thomas, G. W., and Darrow, R. A. 1956. Response of Pricklypear to Grazing and Control Measures, Texas Range Station, Barnhart. Texas Agricultural Experiment Station Progress Report No. 1873.

Young, Vernon A. ET AL. 1951. Recent Developments in the Chemical Control of Brush on Texas Ranges. Texas Agricultural Experiment Station Bulletin $\mathbf{7 2 1}$ (Rev).

\section{LANGUAGE AND WRITING}

Recognition of language-its function and its subtleties-come more easily in speaking and listening than in writing ... Writing creates an awareness of language for strengthening the instruments of thought ... The uses of language affect the uses of mind.-Jerome S. Bruner 